\title{
A Case of Mucosa-Associated Lymphoid Tissue Lymphoma in Sublingual Glands without Autoimmune Disease
}

\author{
Ki Ju Cho ${ }^{1}$, Jin Pyeong Kim ${ }^{1,2}$, Seung Hoon Woo ${ }^{1,2}$, and Jung Je Park ${ }^{1,2}$ \\ ${ }^{1}$ Department of Otolaryngology, ${ }^{2}$ Institute of Health Sciences, College of Medicine, Gyeongsang National University, Jinju, Korea
}

\section{자가면역질환 없이 설하선에 발생한 MALT 림프종 1예}

조기주 ${ }^{1} \cdot$ 김진평 $^{1,2} \cdot$ 우승훈 ${ }^{1,2} \cdot$ 박정제 $^{1,2}$

경상대학교 의과대학 이비인후과학교실, ${ }^{1}$ 건강과학연구원 ${ }^{2}$

\author{
Received July 22, 2015 \\ Revised September 8, 2015 \\ Accepted September 18, 2015 \\ Address for correspondence \\ Jung Je Park, MD, PhD \\ Department of Otolaryngology, \\ College of Medicine, \\ Gyeongsang National University, \\ 79 Gangnam-ro, Jinju 52727, Korea \\ Tel $+82-55-750-8698$ \\ Fax $+82-55-759-0613$ \\ E-mail capetown@hanmail.net
}

\begin{abstract}
Mucosa-associated lymphoid tissue (MALT) lymphomas are low-grade extranodal B-cell lymphomas that may involve various sites in the head and neck including the thyroid, salivary, and lacrimal glands. In particular, primary salivary gland MALT lymphoma is rare, with sublingual gland tumors especially rarer and frequently malignant. In Korea, there has been no reported case of MALT lymphoma in sublingual glands. Here we report a case of a MALT lymphoma in the sublingual gland. Korean J Otorhinolaryngol-Head Neck Surg 2016;59(6):458-61
\end{abstract}

Key Words Mucosa-associated lymphoid tissue lymphoma $\cdot$ Salivary gland Sublingual gland.

\section{서 론}

침샘종양은 전체 두경부 암 가운데 3.5 10\% 정도를 차지 할 만큼 드물다. 특히, 설하선에 발생하는 종양은 매우 드물며 양성보다는 악성이 더 많다고 알려져 있다. ${ }^{1)}$ 또한 아직까지 설 하선에 발생한 mucosa-associated lymphoid tissue(MALT) 림프종의 경우는 국내 문헌 검색(Korean Studies Information Service System \& KoreaMed)상 현재 보고된 바가 없다.

최근 저자들은 67세 남자가 6개월 전부터 발생한 좌측 설하 선의 무통성 종괴를 주소로 내원하여, 좌측 설하선의 악성 종양 의심 하에 좌측 설하선 절제술 후 병리 조직 검사결과 MALT 림프종으로 확진된 예를 경험하였기에 보고하는 바이다.

\section{증 례}

67세 남자 환자가 6개월 전부터 발생한 좌측 설하선의 무통
성 종괴를 주소로 내원하였다. 환자는 Sjögren 증후군, 류마 티스 질환 등의 자가면역질환을 포함한 특별한 과거력은 없 었으며, 약 30 갑년의 흡연력이 있었고 가족력에서도 특이사 항은 없었다. 환자는 내원 당시 구강 내 종괴로 인한 불편감 외에 야간발한, 발열, 체중감소 등의 증상은 없었고, 신체검 진에서 좌측 설하선 부분에 $4 \times 4 \mathrm{~cm}$ 크기의 단단하고 둥근 종괴가 촉지되었으며 압통은 없었다(Fig. 1A), 경부에서 비정 상적인 림프절은 촉지되지 않았다. 일반 혈액검사, 소변검사, 심전도에서 특이소견은 발견되지 않았다.

경부 자기공명영상(MRI)에서 좌측 설하선에 $4.2 \mathrm{~cm}$ 크기 의 조영 증강된 종괴가 관찰되었다(Fig. $1 \mathrm{~B}, \mathrm{C}$, and D). 좌측 설하선 부위에서 세침 흡인검사 시행 후 악성이 아니라는 진단 을 받았으나, 설하선의 종양은 양성보다는 악성이 많다는 임 상적 판단으로 보다 정확한 진단 및 치료를 위해 좌측 설하 선 절제술을 시행하였다. 수술로 떼어낸 종괴는 크기가 4.6× $4.5 \times 1.8 \mathrm{~cm}$ 였고, 겉이 매끈하고 실질은 노란 회백색의 둥근 

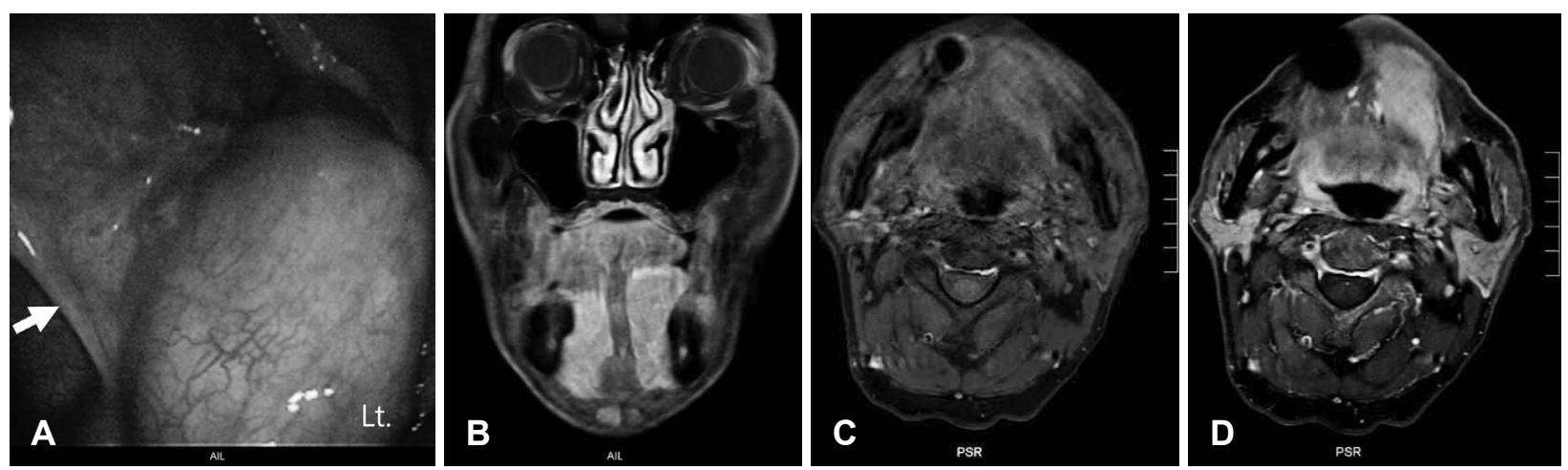

Fig. 1. About $4 \times 4 \mathrm{~cm}$ sized mass with smooth surface, firm and round shape located in left floor of mouth (left sublingual area) (arrow: frenulum) (A). Preoperative coronal MRI (T1) shows high signal in left sublingual area (B). Preoperative axial MRI (T1) shows high signal in left sublingual area: non-enhance (C), enhance (D).

모양이었다(Fig. 2A). 동결절편 검사결과는 림프종이 의심된 다는 소견이었다. 이후 $\mathrm{H \& E}$ 조직검사결과 저배율(100배)에 서는 원래의 침샘(salivary gland)구조를 알아보기 힘들 정도 로 많은 림프구(lymphocyte)가 보이며, 고배율(400배)에서 보았을 때 침샘의 선방(acinus) 내부에 림프구(lymphocyte) 가 침윤해 있는 것을 관찰할 수 있었다(Fig. 2B and C) 면역조 직화학검사(immunohistochemical stain) 결과는 cluster of differentiation(CD)3 양성, CD5 양성, CD20에 뚜렷한(predominant) 양성, cytokeratin 양성(remaining duct), Ki-67 10\% 저등도(low grade), $\mathrm{CD} 10$ 음성, $\mathrm{CD} 30(\mathrm{Ki}-1)$ 음성이었다. 병리 과에서는 앞의 결과를 바탕으로 악성 림프종(malignant lymphoma), 설하선을 침윤한 림프절외 변연대 림프종(extranodal marginal zone lymphoma, in sublingual gland with involvement of regional lymph nodes)으로 진단하였다(Fig. 2D, E, and F).

환자는 혈액종양내과로 전과되어 병기결정을 위한 골수생 검, 상부위장관내시경 및 $\mathrm{FDG}-\mathrm{PET} / \mathrm{CT}$ 스캔을 시행하였다. 최종적으로 설하선 및 위에 침윤한 림프절외 변연대 $\mathrm{B}$ 세 포 림프종(extrnodal marginal zone B cell lymphoma)-stage IV(Ann-Arbor stage IV AE)(sublingual gland, stomach)가 진단되었고, rituximab, cyclophosphamide, vincristine, prednisolone regimen을 이용한 항암화학요법을 지금까지 4회 시행받았다. 현재 나머지 항암요법 계획하에 경과 관찰 중이 며 특별한 술 후 합병증 및 항암화학요법으로 인한 합병증은 관찰되지 않고 있다.

\section{고 찰}

설하선에 발생하는 종양은 악성이 많으며, 주로 선양암성낭 종(adenoid cystic carcinoma) 또는 점액표피양암종(mucoepidermoid carcinoma)이 대표적인 예이다. 또한 통증을 동
반하지 않는 경우가 대부분이다. ${ }^{1)}$ 이번 증례의 경우 환자가 설 하선에 발생한 무통성의 종괴를 주소로 내원하였기 때문에 저자들은 선양암성낭종 또는 점액표피양암종을 의심하였다. 하지만, 조직검사 결과는 MALT 림프종이 진단되었다. 침샘 림프종은 전체 침샘 종양의 약 $3 \%$ 에 해당한다. 이 중 $80 \%$ 가 이하선, 악하선은 $16 \%$, 설하선 $2 \%$, 작은 침샘 $2 \%$ 정도를 차 지한다고 알려져 있다. ${ }^{2}$ 이렇듯 설하선에서 발생하는 침샘 림프종이 극히 드물기 때문에 이것을 의심하기 쉽지가 않다. 또한 밝혀진 발병기전으로 여러 감염 요인, 예를 들면 EpsteinBarr virus, human immunodeficiency virus, Helicobacter pylori infection, hepatitis $\mathrm{C}$ 등에 의해 돌연변이를 과정을 거쳐 림프구의 증식 또는 악성변화를 일으켜 림프종이 생긴 다고 알려져 있다. ${ }^{3}$

MALT 림프종은 서서히 크기가 증가하는 무증상(asymptomatic)의 점막하부종(submucosal swelling)의 임상적 특징 을 가진다. 이하선에 발병할 경우 크기 증가에 따라 안면신경 마비(facial nerve palsy)가 나타나기도 한다. ${ }^{3)}$

영상의학적 감별방법으로 $\mathrm{CT}$ 또는 MRI에서 림프절침범 (nodal involvement)한 경우 다수의 경계가 명확하며, homogeneously/intermediate signal을 가지는 종괴(mass)가 관찰 된다. 본 증례의 경우와 같이 실질을 침범(parenchymal involvement)의 경우 diffuse infiltration 또는 infiltrative border를 가지는 종괴가 관찰된다. ${ }^{4}$ 본 증례의 환자의 경우에는 해당하지 않지만, 대개 MALT 림프종은 Sjögren 증후군과 같은 자가면역질환을 동반하는 경우가 많아서 이것을 확인 하는 것도 중요하다. ${ }^{5}$

조직병리학적으로 림프절외림프종은 반응성과 종양성의 림 프양 침윤을 구별할 목적으로 면역조직화학 검사를 시행하 게 된다. 면역조직화학 검사에서 $\mathrm{CD} 3, \mathrm{CD} 5, \mathrm{CD} 43$ 음성, $\mathrm{B}$ 세 포 항원인 $\mathrm{CD} 20$ 양성, $\kappa$ 또는 $\lambda$ 면역글로불린 경쇄의 단일 성 염색소견 등이 MALT 림프종을 시사하는 소견이다. ${ }^{6}$ 최근 
polymerase chain reaction기법이나 Southern blot을 이용 한 MALT 림프종 진단 방법에 대한 연구가 발표된 적이 있지 만, 이것을 실제 임상에 정규적인 검사로 널리 사용하고 있지 않는 실정이다.

한편, MALT 림프종은 다른 저악성도 B세포 비호지킨 림프 종의 아형들보다 덜 침습적인 것으로 보고되고 있다. 한 부위
에 오랫동안 국소화되어 있고 비교적 서서히 진행하는 특성 이 있기 때문에 절제나 방사선 치료가 가능한 경우가 많다. 다 발성이거나 파종성의 경우에는 복합 항암화학요법을 시행하 거나, 방사선 치료를 추가하여 시행할 수 있다.

본 증례는 설하선에 발생하는 종양으로 환자가 내원하였 을 때 기존의 진단 검사 결과가 기대와 다를 경우, MALT 림
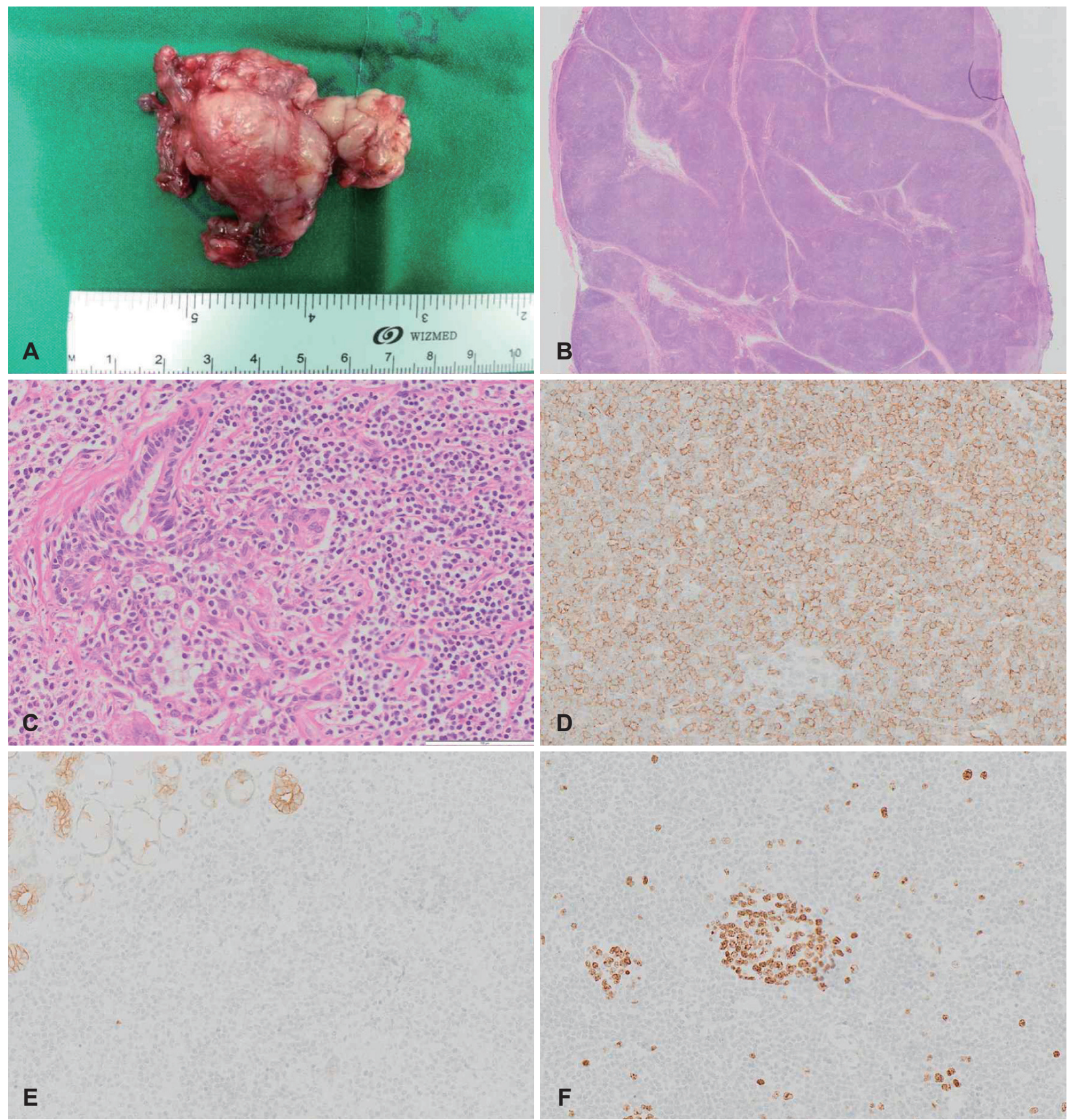

Fig. 2. The resected specimen (left sublingual gland): $4.6 \times 4.5 \times 1.8 \mathrm{~cm}$-sized, yellowish round shaped extranodal marginal zone B-cell lymphoma of the submandibular gland $(A)$. The salivary gland parenchyma is replaced by lymphoma composed of small cells with abundant pale cytoplasm. Note the presence of reactive germinal centers as well as numerous small lymphoid cells invading the epithelial ducts (lymphoepithelial lesions) (H\&E: B, original magnification $\times 100$ ), original magnification $\times 400)(B$ and C). Immunohistochemical staining discloses CD 20-positive in brownish stains $(\times 100)(D)$, cytokeratin positive in remaining duct $(\times 100)(E)$, Ki-67 positive about $10 \%(\times 100)(F)$. 
프종의 가능성을 염두에 두고 진단 및 치료를 해 볼 수 있다 는 것에 그 의미가 있다.

\section{REFERENCES}

1) Zdanowski R, Dias FL, Barbosa MM, Lima RA, Faria PA, Loyola AM, et al. Sublingual gland tumors: clinical, pathologic, and therapeutic analysis of 13 patients treated in a single institution. Head Neck 2011;33(4):476-81.

2) Vega F, Lin P, Medeiros LJ. Extranodal lymphomas of the head and neck. Ann Diagn Pathol 2005;9(6):340-50.

3) Triantafillidou K, Dimitrakopoulos J, Iordanidis F, Gkagkalis A. Extranodal non-hodgkin lymphomas of the oral cavity and maxillofacial region: a clinical study of 58 cases and review of the literature. $\mathrm{J}$
Oral Maxillofac Surg 2012;70(12):2776-85.

4) Lee YY, Wong KT, King AD, Ahuja AT. Imaging of salivary gland tumours. Eur J Radiol 2008;66(3):419-36.

5) Zintzaras E, Voulgarelis M, Moutsopoulos HM. The risk of lymphoma development in autoimmune diseases: a meta-analysis. Arch Intern Med 2005;165(20):2337-44.

6) Bhattacharyya N, Frankenthaler RA, Gomolin HI, Kadin ME, Lauretano AM. Clinical and pathologic characterization of mucosaassociated lymphoid tissue lymphoma of the head and neck. Ann Otol Rhinol Laryngol 1998;107(9 Pt 1):801-6.

7) Honda K, Kusama H, Takagi S, Sekine S, Noguchi M, Chiba H. Diagnosis of intra-oral MALT lymphoma using seminested polymerase chain reaction. Br J Oral Maxillofac Surg 2004;42(1): 28-32. 